\title{
PENDIDIKAN ISLAM DALAM SISTEM PENDIDIKAN NASIONAL
}

\author{
Dhian Marita Sari \\ Sekolah Tinggi Ilmu Tarbiyah Madani Yogyakarta \\ Email: dhianfirdausa@gmail.com
}

\begin{abstract}
Abstrak:
Islam adalah agama universal yang sarat dengan akhlak sebagai bentuk kesempuraan. Dalam sistem pendidikan nasional pendidikan islam memperkuat kedudukannya sebagai salah satu tonggak penanaman tata nilai dalam masyarakat. Maka sudah selayaknya pendidikan islam dapat membangung konsep masyarakat belajar dan menjadi pioneer untuk mencapai visi dan misi dari pendidikan nasional Indonesia. Disitu mengkaji kedudukan, defisi dan peran strategis pendidikan Islam menjadi begitu penting untuk mengoptimalkan tujuan dan fungsinya dalam masyarakat.
\end{abstract}

Kata Kunci: Penddikan Islam, definisi, Kendudukan

Islam is a universal religion which is full of morals as a form of perfection. In the national education system, Islamic education strengthens its position as one of the pillars of planting values in society. So it is proper for Islamic education to build the concept of a learning society and become a pioneer in achieving the vision and mission of Indonesia's national education. There it examines the position, definition and strategic role of Islamic education so important to optimize its goals and functions in society.

Keywords: Islamic education, definition, occupation 


\section{A. Pendahuluan}

Indonesia sebagai bangsa dengan penduduk islam terbesar didunia dikenal karena sistem nilai yang kuat. Suatu bangsa akan diakui eksistensinya apabila Bangsa tersebut mampu menciptakan suatu kondisi masyarakat yang maju dan sejahtera. Dalam hal ini pendidikan menempati posisi yang sentral dan strategis untuk menciptakan masyarakat yang demikian. Namun suatu Bangsa juga membutuhkan kondisi harmonis dalam kehidupan rakyatnya, sikap toleran, jauh dari konflik dan lain sebagainya. Bangsa Indonesia yang plural dari berbagai aspek kehdiudupan, baik agama, bahasa, suku dan budaya. Kondisi pluralitas ini membutuhkan suatu pijakan moral yang kuat dari warga masyarakatnya. Untuk membentuk ahlak atau moral masyarakat, maka agama memainkan perannya sebagai sistem nilai dalam membentuk ahlak mulya masyarakat dari pembentukan individu yang baik, yang sejalan dengan tujuan dan fungsi agama tersebut.

Islam sebagai agama mayoritas di Indonesia, harus memainkan peran dalam pembentukan ahlak masyarakat indonesia atau ahlak ummat Islam. Karena itulah, pendidikan Islam harus mampu menananmkan dan melahirkan individu muslim yang baik tersebut, terlebih-lebih setelah pendidikan Islam masuk dalam undang-undang sistem pendidikan Nasional. Saat ini, Bangsa Indonesia sedang berusaha keras untuk mengembangkan masa depannya yang lebih cerah dengan 
melaksanakan transformasi dirinya menjadi "masyarakat belajar", yakni suatu masyarakat yang memiliki nilai-nilai dimana belajar merupakan kewajiban yang harus dilaksanakan setiap ada kesempatan bagi setiap warga negara. Sebagai suatu bangsa yang sedang tumbuh dan berkembang, setiap warga negara diharapkan dapat memanfaatkan waktunya yang ada untuk menambah pengetahuan dan ketrampilan, sehingga upaya mengejar ketertinggalan dari bangsa-bangsa yang sudah maju dapat dipercepat. ${ }^{1}$ Namun hal tersebut di atas menuntut adanya pembinaan terhadap nilai dan sikap yang dilaksanakan secara seimbang antara pendidikan Cognitive (kognitif, pengetahuan dan kecerdasan), Psychomotor (psikomotor, ketrampilan dan kekaryaan), Affective (afektif, sikap, mental, emosi, perasaan) yang dilandasi dengan keimanan dan ketaqwaan kepada Allah SWT, serta kepedulian terhadap lingkungan dan masyarakat sekitar oleh pihak yang berwenang, dalam hal ini pemerintah untuk mengakomodir itu semua. Hal ini dapat diidentifikasikan sebagai modal pendidikan ideal yang didambakan setiap warga negara. ${ }^{2}$ Dalam tulisan ini saya akan mengkaji masalah posisi pendidikan Islam dalam sistem pendidikan Nasional.

\footnotetext{
${ }^{1}$ Depag RI, Pola Pengembangan Pondok Pesantren (Jakarta: Ditpekapontren Ditjen Kelembagaan Agama Islam Depag, 2003), h. 64.

2 Ibid. 64-65.
} 


\section{B. Definisi Pendidikan, Fungsi dan Tujuan Pendidikan Islam}

Secara etimologis, pendidikan berasal dari kata didik yang mendapat awalan pen- dan akhiran -an yang berarti proses, perbuatan, cara mendidik, pelihara dan ajar. ${ }^{3}$ Istilah pendidikan diterjemahkan ke dalam bahasa Inggris dengan education yang berarti pengembangan atau bimbingan. Dalam bahasa Arab istilah ini sering diterjemahkan dengan tarbiyah yang berarti pendidikan. ${ }^{4}$ Dalam konteks Islam, istilah pendidikan kadang kala digunakan dengan kata tarbiyah, ta'lim, dan ta'dib. Tarbiyah dengan kata dasarnya rabba yang berarti mendidik, membesarkan, mengasuh, berkembang dan meningkat (tumbuh). ${ }^{5}$

Kata tarbiyah khususnya dalam al-Qur'an menunjuk pada masa anak-anak dan berkaitan dengan usaha yang wajib dilakukan, dan merupakan beban orang-orang dewasa terutama orang tua terhadap anaknya. ${ }^{6}$ Selain kata tarbiyah, dalam konteks Islam, istilah pendidikan kadang kala digunakan kata ta'lim dengan kata dasarnya 'allima yang berarti mengajar (tansfer of

\footnotetext{
3 Tim Penyusun Kamus Pusat, Kamus Besar Bahasa Indonesia, h. 204; Agus Basri, Pendidikan Islam sebagai Penggerak Pembaharuan Islam (Bandung: al-Ma'arif, 1984), h. 19.

4 Ramayulis, Ilmu Pendidikan Islam (Jakarta: Kalam Mulia, 1994), h. 1; Zakiah Daradjat, Ilmu Pendidikan Islam, cet. III (Jakarta: Bumi Aksara, 1996), h. 25.

${ }^{5}$ Mahmud Yunus, Kamus Arab-Indonesia, cet. III (Jakarta: Hidakarya Agung, 1990), h. 138; Munjid,(Beirut: Dar el-Machreq, 1986), h. 247; Syed Muhammad Naquib alAttas, Konsep Pendidikan Islam; Suatu Rangka Pikir Pembinaan Filsafat Pendidikan Islam, Penerjemah Haidar Bagir. cet. VII (Bandung: Mizan, 1996), h. 72

6 Maksum, Madrasah, Sejarah, dan Perkembangannya, cet. II (Jakarta: Logos Wacana Ilmu, 1999), h. 16
} 
knowledge). Seperti yang termaktub pada Surat al-Baqarah [2] ayat 31 yang artinya:

Dan Dia mengajarkan kepada Adam nama-nama (benda-benda) seluruhnya, kemudian mengemukakannya kepada para Malaikat lalu berfirman: "Sebutkanlah kepada-Ku nama benda-benda itu jika kamu memang orang-orang yang benar!" (QS. Al-Baqarah [2]: 31).

Herry Noer Ali mengutip pendapatnya Abdul Fattah Jalal, mengatakan bahwa ta'lim adalah proses pembelajaran secara terus-menerus yang terjadi sejak manusia itu lahir melalui pengembangan beberapa fungsi pendengaran, penglihatan dan hati. Dan pengembangan tersebut merupakan tanggung jawab orang dewasa ketika seseorang masih kecil, namun setelah mereka dewasa, hendaknya manusia belajar secara mandiri sampai ia tidak mampu lagi meneruskan belajarnya. ${ }^{7}$

Kata mendidik (tarbiyah) dan mengajar (ta'lim) mempunyai pengertian yang berbeda. Menurut Mahmud Yunus, mendidik berarti menyiapkan anak dengan segala macam jalan supaya dapat mempergunakan tenaga dan bakatnya dengan sebaikbaiknya sehingga mencapai kehidupan yang sempurna dalam masyarakat tempat tinggalnya. Sedangkan mengajar berarti mentransfer ilmu pengetahuan kepada anak supaya ia

\footnotetext{
7 Herry Noer Ali, Ilmu Pendidikan Islam (Jakarta: Logos, 1999), h. 9; Menurut AlQurtubi, kata lata'lamu dalam ayat ini adalah ketidaktahuan manusia terhadap tiga hal; pertama, tidak mengetahui sesuatu janji yang diucapkan dan dikukuhkan dalam hati oleh orang tuanya. Kedua, tidak mengetahui sesuatu yang berhubungan dengan qadla dan qadar (ketentuan) Allah kepada manusia, baik yang berbentuk kebahagiaan maupun penderitaan. Ketiga, tidak mengetahui sesuatu yang berguna bagi manusia itu sendiri.
} 
pandai. ${ }^{8}$ Sehinagga dapat dipahami bahwa mendidik mempunyai cakupan yang lebih luas dan mendalam dari mengajar. Sebagaimana yang diungkap oleh Mahmud Yunus bahwa mengajar adalah salah satu segi dari beberapa segi pendidikan. Dalam mengajar, pendidik memberikan ilmu, pendapat, dan pikiran kepada peserta didik menurut metode yang disukainya.

Pendidik berbicara, peserta didik mendengar; pendidik aktif, peserta didik pasif. Sedangkan di dalam mendidik, pendidik memberi dan peserta didik harus membalas, menyelidiki, dan memikirkan soal-soal sulit, mencari jalan mengatasi kesulitan tersebut. ${ }^{9}$ Selain kata tarbiyah dan ta'lim, istilah pendidikan dalam konteks Islam juga digunakan kata ta'dib, berarti pendidikan yang berhubungan dengan perilaku atau akhlak dalam kehidupan yang lebih mengacu pada peningkatan martabat manusia. ${ }^{10}$ Jika dibandingkan dari ketiga istilah pendidikan dalam konteks Islam di atas, maka perbedaan istilah tersebut, tarbiyah mengandung makna lebih luas, tercakup di dalamnya pengertian ta'lim dan ta' dib. Istilah ta'lim lebih bersifat informatif, yaitu usaha pemberian ilmu pengetahuan sehingga

\footnotetext{
8 Mahmud Yunus, Pendidikan dan Pengajaran, cet. III (Jakarta: Hidakarya Agung, 1990), h. 19

9 Yunus, Pendidikan dan Pengajaran, h. 25; Senada dengan itu, Azra mengemukakan bahwa pendidikan lebih daripada sekedar mengajar. Pendidikan salah satu proses transformasi nilai dan pembentukan kepribadian dengan segala aspeknya. Pengajaran hanya sebagai suatu proses transfer ilmu belaka, lebih berorientasi pada pembentukan para spesialis yang terkurung dalam ruang spesialisasinya yang sempit. Lihat; Azra, Pendidikan Islam; Tradisi dan Modernisasi, h. 3.

${ }^{10}$ Abuddin Nata, Filsafat Pendidikan Islam (Jakarta: GayaMuda Pratama, 2005), h. 9.
} 
seseorang menjadi berilmu (tahu). Sedangkan ta'dib mengesankan proses pembinaan terhadap sikap moral dan etika dalam kehidupan yang lebih mengacu pada peningkatan martabat manusia.

Sedangkan pendidikan ditinjau dari segi terminologis juga mempunyai banyak pengertian. Di antaranya seperti yang diungkap oleh Crow dan Crow, pendidikan sebagai proses yang berisi berbagai macam kegiatan yang sesuai dengan kegiatan seseorang untuk kehidupan sosialnya dan membantunya meneruskan kebiasaan-kebiasaan generasi. ${ }^{11}$ Dalam Ensiklopedi Pendidikan, istilah pendidikan diartikan dengan semua perbuatan dan usaha dari generasi tua untuk mengalihkan pengetahuannya, pengalamannya, kecakapannya, serta keterampilannya kepada generasi muda sebagai usaha menyiapkannya agar dapat memenuhi fungsi hidupnya baik jasmaniah maupun rohaniyah. ${ }^{12}$

Berbeda dengan itu, Zakiah Daradjat mengartikan pendidikan dengan suatu usaha dan kegiatan yang dilakukan oleh orang dewasa dalam menyampaikan pelajaran, memberi contoh, melatih keterampilan berbuat, memberi motivasi dan menciptakan lingkungan sosial yang mendukung pembentukan

11 Zahara Indris dan Lisna Jamal, Pengantar Ilmu Pendidikan, Jilid I (Jakarta: Grasindo, 1992).

12 Soegarda Poerbakawatja dan A. H. Harahap, Ensiklopedi Pendidikan, cet. II (Jakarta: Gunung Agung, 1981), h. 257. 
kepribadian peserta didik. ${ }^{13}$ Sementara itu, M. Arifin mengemukakan bahwa pendidikan adalah suatu usaha untuk mengarahkan pertumbuhan dan perkembangan hidup manusia (sebagai makhluk pribadi dan sosial), kepada titik optimal kemampuannya untuk memperoleh kesejahteraan hidup di dunia dan kebahagiaan hidup di akhirat. ${ }^{14}$ Ahmad D. Marimba mengartikan pendidikan sebagai bimbingan atau pimpinan secara sadar oleh pendidik terhadap perkembangan jasmani dan rohani terdidik menuju terbentuknya kepribadian utama.

\section{Dalam Terminologi yang Berbeda}

Ramayulis mendefenisikan pendidikan sebagai segala usaha orang dewasa dalam pergaulan dengan anak-anak untuk memimpin perkembangan jasmani dan rohaninya ke arah kedewasaan. Sedangkan Zuhairini mendefenisikan pendidikan dengan aktivitas untuk mengembangkan seluruh aspek kepribadian manusia yang berjalan seumur hidup. Dengan kata lain, bahwa pendidikan tidak hanya berlangsung di dalam kelas tetapi berlangsung pula di luar kelas. Pendidikan bukan bersifat formal saja, namun mencakup aspek non-formal. ${ }^{15}$

13 Zakiah Daradjat, Ilmu Pendidikan Islam, h. 27; Bandingkan; Mohamad Ali, "Reorientasi Makna Pendidikan: Urgensi Pendidikan Terpadu," dalam Marzuki Wahid, dkk., ed., Pesantren Masa Depan (Bandung: Pustaka Hidayah, 1999), h. 171.

${ }_{14}$ M. Arifin, Ilmu Pendidikan Islam: Suatu Tinjauan Teori dan Praktis Berdasarkan Pendekatan Interdisipliner, cet. IV (Jakarta: Bumi Aksara, 1996), h. 12.

15 Zuhairini, dkk., Filsafat Pendidikan Islam, cet. II (Jakarta: Bumi Aksara, 1995), h. 149. 
Secara lebih luas dan Nana Sudjana mendefenisikan pendidikan sebagai usaha sadar yang bertujuan dan usaha mendewasakan peserta didik (anak). Kedewasaan ini antara lain mencakup kedewasaan intelektual, sosial, moral, dan tidak semata-mata kedewasaan dalam arti fisik. Pendidikan juga merupakan suatu proses budaya untuk meningkatkan harkat dan martabat manusia, melalui proses yang panjang dan berlangsung sepanjang hayat. ${ }^{16}$ Dari beberapa pengertian pendidikan yang dikemukakan oleh para ahli di atas, maka penulis berkesimpulan bahwa pendidikan merupakan usaha yang dilakukan oleh seseorang atau sekelompok orang dalam rangka membina dan mengembangkan potensi peserta didik agar mampu mengenal diri, lingkungan dan Tuhannya, sehingga menjadi manusia yang bermartabat, bermoral dan berilmu serta mampu membawa dirinya kepada keseimbangan hidup di dunia dan di akherat.

Pendidikan Islam menurut Zarkowi Soejoeti sebagaimana yang dituturkan oleh M.Ali Hasan dan Mukti Ali, terbagi dalam tiga pengertian. Pertama "Pendidikan Islam" adalah jenis pendidikan yang pendirian dan penyelenggaraannya didorong oleh hasrat dan semangat cita - cita untuk mengejawantahkan nilai-nilai Islam, baik yang tercermin dalam nama lembaganya, maupun dalam kegiatan-kegiatan yang diselenggarakan. Di sini kata Islam ditempatkan sebagai sumber nilai yang akan

16 Nana Sudjana, Pembinaan dan Pengembangan Kurikulum di Sekolah, cet. II (Bandung: Sinar Baru, 1991), h. 2. 
diwujudkan dalam seluruh kegiatan pendidikan. Kedua, jenis pendidikan yang memberikan perhatian sekaligus menjadikan ajaran Islam sebagai pengetahuan untuk program studi yang diselenggarakan. Di sini kata Islam ditempatkan sebagai bidang studi, sebagai ilmu, dan diperlakukan sebagai ilmu yang lain. Ketiga, jenis pendidikan yang mencakup kedua pengertian di atas. Di sini kata Islam ditempatkan sebagai sumber nilai sekaligus sebagai bidang studi yang ditawarkan melalui program studi yang diselenggarakan. ${ }^{17}$

Adapun Pendidikan Islam merupakan suatu kegiatan pendidikan yang bersumber dari dogma ajaran Islam dengan nilai-nilai universal yang terkandung di dalamnya yang senantiasa mempertimbangkan pengembangan fitrah manusia atau potensi-potensi yang dimiliki manusia selaku makhluk.. ${ }^{18}$ Dengan demikian segala usaha dalam mempelajari pendidikan Islam tidak dapat menghilangkan landasan historisnya yang merupakan bagian integral dari sejarah Islam.

Pendidikan Islam bersumber pada ajaran Islam yang menggambarkan bahwa pendidikan Islam memiliki perbedaan yang sangat esensial dan pokok dengan model pendidikan lain yang cenderung bersifat pragmatis-sekularistik yang hanya terbatas pada sumber dan penyebaran nilai-nilai kemanusian

\footnotetext{
17 M. Ali Hasan, Mukti Ali, Kapita Selekta Pendidikan Islam (Jakarta: CV. Pedoman Ilmu Jaya, 2003), h. 45.

18 Lihat Mapangganro, Sistem dan Metode Pendidikan Islam dalam Upaya meningkatkan Kualitas Bangsa Indonesia menyongsong Era Industrialisasi, makalah yang disampaikan dalam seminar IKA tanggal 26 Agustus 1995, h. 3.
} 
secara universal tanpa pernah mengaitkannya sama sekali dengan nilai-nilai ketuhanan. Menurut M. Yusuf al-Qardhawi, pendidikan Islam merupakan pendidikan manusia seutuhnya, akal dan hatinya, rohani dan jasmaninya, akhlak dan keterampilannya. Sementara itu Hasan Langgulung merumuskan pendidikan Islam sebagai suatu proses penyiapan generasi muda untuk mengisi peranan, memindahkan pengetahuan dan nilainilai Islam yang diselaraskan dengan fungsi manusia untuk beramal di dunia dan memetik hasilnya di akhirat. ${ }^{19}$

Sejalan dengan itu, Muhammad Atiyah Al-Ibrasyi berpendapat bahwa pendidikan Islam itu adalah pendidikan yang berdasarkan pada etika Islam, pembentukan moral, dan latihan jiwa. ${ }^{20}$ Sehingga, tujuan akhir pendidikan Islam tersebut adalah membentuk manusia yang bertakwa supaya selamat dalam kehidupannya, sebagaimana terkandung dalam Surat Ali Imran [3] ayat 102 yang artinhya: " Hai orang-orang yang beriman, bertakwalah kepada Allah sebenar-benar takwa kepada-Nya; dan janganlah sekali-kali kamu mati melainkan dalam keadaan beragama Islam." (QS. Ali Imran [3]: 102).

Pendidikan Islam dapat juga diartikan dengan pengembangan pikiran manusia dan penataan tingkah laku serta emosinya berdasarkan Agama Islam, dengan maksud

${ }^{19}$ Hasan Langgulung, Beberapa Pemikiran tentang Pendidikan Islam (Bandung: AlMa`arif, 1980), h. 94.

20 Muhammad Atiyah Al-Ibrasyi, Dasar-Dasar Pendidikan Islam. Ter. Tasirun Sulaiman, (Ponorogo: PSIA, 1991), h. 1. 
merealisasikan tujuan Islam dalam kehidupan individu dan masyarakat yakni dalam seluruh lapangan kehidupan. ${ }^{21}$ Endang Saefuddin Anshari melihat pendidikan Islam sebagai proses bimbingan (pimpinan, tuntutan, usulan) oleh subyek didik terhadap perkembangan jiwa (pikiran, perasaan, kemauan, intuisi, dan sebagainya) dan raga obyek didik dengan bahanbahan materi tertentu, pada waktu tertentu, dengan metode tertentu dan dengan alat perlengkapan yang ada kearah terciptanya pribadi tertentu disertai evaluasi sesuai dengan ajaran Islam. ${ }^{22}$

Secara lebih teknis Endang Saifuddin Anshari memberikan pengertian pendidikan Islam sebagai proses bimbingan (pimpinan, tuntutan, usulan) oleh subjek didik terhadap perkembangan jiwa (pikiran, perasaan, kemauan, intuisi, dan sebagainya) dan raga objek didik dengan bahan-bahan materi tertentu, pada jangka waktu tertentu, dengan metode tertentu dan dengan alat perlengkapan yang ada ke arah terciptanya pribadi tertentu disertai evaluasi sesuai dengan ajaran Islam. ${ }^{23 S e d a n g k a n}$ yang dimaksud pendidikan Islam di sini adalah upaya mempersiapkan anak didik atau individu dan menumbuhkan baik jasmani maupun rohaninya agar dapat memahami dan

21 Abdurrahman An-Nahlawi, Prinsip-Prinsip dan Metode Pendidikan Islam. Penerjemah Herry Noer Ali (Bandung: CV. Diponegoro, 1989), h. 49.

22 23Endang Saefuddin Anshari, Pokok-pokok Pikiran Tentang Islam, (Jakarta: Usaha Enterprise, 1976), h. 85.

23 Endang Saifuddin Anshari, Pokok-pokok Pikiran tentang Islam (Jakarta: Usaha Enterprise, 1976), h. 85. 
menghayati hakekat kehidupan dan tujuan hidupnya mengapa ia diciptakan, dan dapat menjadi anggota masyarakat yang berguna bagi dirinya dan umatnya.

Hasan Langgulung juga mendefinisikan pendidikan Islam sebagai proses untuk mempersiapkan generasi muda untuk memainkan peran, memindahkan pengetahuan dan nilai-nilai Islam yang diselaraskan dengan fungsi manusia untuk beramal di dunia dan menikmati hasilnya di akhirat. ${ }^{24}$ Sedangkan Ahmad D. Marimba mendefinisikan pendidikan Islam sebagai bimbingan jasmani dan ruhani menuju kepada terbentuknya kepribadian utama menurut ukuran Islam. ${ }^{25}$ Sedangkan H. Haidar Putra Daulay memberikan kesimpulan atas semua pendefinisian tentang pendidikan Islam, pendidikan Islam baginya adalah proses pembentukan manusia seutuhnya sesuai dengan Tuntunan Islam. ${ }^{26}$ Sedangkan Azyumardi Azra melihat pendidikan Islam sebagai salah satu aspek dari ajaran Islam secara keseluruhan, itulah sebabnya tujuan pendidikan Islam tidak terlepas dari tujuan hidup manusia dalam Islam; yaitu untuk menciptakan pribadi-pribadi hamba Allah yang selalu bertakwa kepada-NYA dan dapat mencapai kehidupan bahagiya di dunia dan akherat. Dalam konteks, sosial masyarakat, bangsa dan negara pribadi

\footnotetext{
${ }^{24}$ Hasan Langgulung, Beberapa Pemikiran Tentang Pendidikan Islam, (Bandung: Al-Ma'rifah, 1980), h. 94.

${ }_{25}$ Ahmad D. Marimba, Pengantar Filsafat Pendidikan Islam, (Bandung: Al-Ma'rifah, 1980), h. 23.

26 27Haidar Putra Daulay, Sejarah Pertumbuhan dan Pembaruan Pendidikan Islam di Indonesia, (Jakarta: Kencana Prenada Media Group, 2007), cet. I., h. 15.
} 
yang bertaqwa inilah yang menjadi rahmatan lil'alamin, baik dalam sekala kecil maupun dalam skala besar. ${ }^{27}$

Selain masalah definisi dan fungsi pendidikan Islam, hal lain yang penting untuk dilihat dari pendidikan Islam tersebut adalah masalah paradigma atau bentuk dari pendidikan Islam tersebut, yang tentunya berbeda dengan pendidikan lain, baik dari aspek definisi, sumber dan tujuannya. Pendidikan Islam haruslah berparadigma Ilahiyah atau teosentrisme, mengingat pendidikan Islam yang merupakan bagian atau aspek dari agama Islam itu sendiri. Dengan demikian, pendidikan Islam harus mengacu pada tuntunan dan kandungan dari sumber ajaran Islam itu sendiri, yakni al-Qur'an dan al-Hadits, serta karya-karya besar para intlektual Islam, baik dari kalangan fukahak, filosof, sufi, teolog. Sehingga ia menyimpulkan bahwa tujuan hidup mansuia dalam Islam merupakan tujuan dari pendidikan Islam itu sendiri, Ciri khas pendidikan Islam itu ada dua macam :

1. Tujuannya : Membentuk individu menjadi bercorak diri tertinggi menurut ukuran Allah.

2. Isi pendidikannya : ajaran Allah yang tercantum dengan lengkap di dalam Al Qur'an yang pelaksanaannya dalam

27 28Dalam hal ini Azra mengutif surat Al-Dzariat ayat 56 dan surat al-Imran ayat 102. Sehingga ia menyimpulkan bahwa tujuan hidup mansuia dalam Islam merupakan tujuan dari pendidikan Islam itu sendiri, Azra, Pendidikan Islam: Tradisi dan Modernisasi Menuju Milenium Baru, h. 8 
praktek hidup sehari-hari dicontohkan oleh Muhammad Rasulullah SAW. ${ }^{28}$

Teori-teori pendidikan Islam yang berkembang di Indonesia secara umum mendefinisikan pendidikan Islam dalam dua tataran: idealis dan pragmatis. Pada tataran idealis, pendidikan Islam diandaikan sebagai suatu sistem yang independen (eksklusif) dengan sejumlah kriterianya yang serba Islam. Definisi ini secara kuat dipengaruhi oleh literatur Arab yang masuk ke Indonesia baik dalam bentuk teks asli, terjemahan, maupun sadurannya. Sedangkan pada tataran pragmatis, pendidikan Islam ditempatkan sebagai identitas (ciri khusus) yang tetap berada dalam konteks pendidikan nasional.

Perkembangan-perkembangan aktual di Indonesia khususnya selama tiga dekade terakhir sangat mempengaruhi munculnya definisi pragmatis ini. ${ }^{29}$ Penulis-penulis Indonesia kontemporer berusaha menjelaskan definisi pendidikan Islam dengan melihat tiga kemungkinan hubungan antara konsep pendidikan dan konsep Islam. Dilihat dari sudut pandang kita tentang Islam yang berbeda-beda, istilah pendidikan Islam tersebut dapat dipahami sebagai :

1. Pendidikan (menurut) Islam

2. Pendidikan (dalam) Islam

3. Pendidikan (agama) Islam

\footnotetext{
28 Azra, Pendidikan Islam: Tradisi dan Modernisasi Menuju Milenium Baru, h. 8. ${ }^{29}$ Ibid. h. 46
} 
Dalam hubungan yang pertama, pendidikan Islam bersifat normatif, sedang dalam hubungan yang kedua, pendidikan Islam lebih bersifat sosio-historis. Adapun dalam hubungan yang ketiga, pendidikan Islam lebih bersifat proses-operasional dalam usaha pendidikan ajaran-ajaran agama Islam. Dalam kerangka akademik, pengertian yang pertama merupakan lahan filsafat pendidikan Islam, dan pengertian yang ketiga merupakan kawasan ilmu pendidikan Islam teoritis. ${ }^{30}$

\section{Pengembangan Pendidikan Islam Di Indonesia}

Kajian-kajian historis menunjukkan bahwa sampai abad ke19, pendidikan Islam, dalam bentuk masjid dan pesantren, masih menjadi lembaga pendidikan yang dominan bagi masyarakat Indonesia. Pergeseran mulai terjadi pada masa penjajahan. ${ }^{31}$ Alasan-alasan tidak dipakainya sistem pendidikan Islam oleh pemerintah Hindia-Belanda itu semata-mata karena pertimbangan aspek didaktis-metodiknya yang tidak baik, menurut Karel A. Steenbrink sebagaimana yang ditulis M. Ali Hasan-Mukti Ali. ${ }^{32}$

Terlepas dari alasan itu, sangat boleh jadi penyebab utama diasingkannya sistem pendidikan Islam karena kemungkinan konsekuensinya tidak menguntungkan kepentingan politik

\footnotetext{
30 Ibid, h. 47

${ }^{31}$ M. Ali Hasan, Mukti Ali, Kapita Selekta Pendidikan Islam (Jakarta: CV. Pedoman Ilmu Jaya, 2003), h. 47.

32 M. Ali Hasan, Mukti Ali, Kapita Selekta Pendidikan Islam, h. 48.
} 
Hindia-Belanda, karena dalam prakteknya pendidikan Islam lebih menekankan kepada aspek keimanan dan keyakinan dalam beragama. Praktek pendidikan seperti ini memberi rangsangan dan motivasi untuk melawan penjajah dan pemerintahan kafir. Pemberlakuan pendidikan pribumi oleh pemerintah HindiaBelanda dapat dianggap awal dari dualisme sistem pendidikan bagi masyarakat Indonesia. Pendidikan Islam tetap berjalan sesuai dengan karakternya dan secara tradisional menjadi andalan masyarakat Indonesia, khususnya kaum muslimin. Sementara sistem pendidikan pribumi ala Belanda terus berkembang dan menjadi pusat pengajaran dan pelatihan bagi kaum elit pribumi yang mempunyai hubungan dengan pemerintah Hindia-Belanda. Dan dalam perkembangannya, dualisme pendidikan ini membawa orientasi wawasan masyarakat Indonesia yang terbelah sesuai dengan karakter masing-masing pendidikan yang ditempuhnya. Namun demikian,orientasi kaum terpelajar yang berlatar pendidikan ala Belanda secara politis lebih siap menangani masalah-masalah kenegaraaan, karena pola pendidikannya sejak awal mempersiapkan mereka untuk menjadi tenaga-tenaga pemerintah. ${ }^{33}$

Kesadaran perlunya mengembangkan orientasi pendidikan Islam yang menyangkut masalah-masalah sosial politik dan ekonomi (keduniawian) akhirnya muncul di kalangan kaum

33 Ibid, h. 48 
muslimin. Hal ini kemudian mendorong dilakukan penyesuaian pendidikan Islam, kurikulum, kelembagaan dan sistem pengajarannya. Upaya penyesuaian pendidikan Islam tersebut terbukti dengan kemunculannya di Minangkabau, tahun 19061930, di Yogyakarta seperti Muhammadiyah, di Jakarta seperti Jam'iat Khair. Masalah pendidikan Islam baru muncul pada segi lingkup sejauh mana pendidikan Islam dikembangkan. Apakah terbatas pada pendidikan Islam dalam pengertian agama secara murni, atau pendidikan Islam dalam pengertian sistem yang mengajarkan berbagai aspek kehidupan yang berdasarkan agama. Hal ini menjadi serius karena akan sangat menentukan pola dan sistem pendidikan nasional secara menyeluruh. Kalangan Islam berpendapat bahwa pendidikan Islam harus dikembangkan di Indonesia sejauh mungkin, sementara kalangan non-Islam membatasinya dalam lingkup pengajaran agama. Namun demikian, akhirnya ketentuan-ketentuan yang lebih tegas tentang pendidikan agama dalam pendidikan nasional telah direkomendasikan oleh Badan Pekerja Komite Nasional Pusat (BPKNP), antara lain :

1. Pelajaran agama dalam semua sekolah, diberikan pada jam pelajaran sekolah.

2. Para guru dibayar oleh pemerintah.

3. Pada sekolah dasar pendidikan ini diberikan mulai kelas IV.

4. Pendidikan tersebut diselenggarakan seminggu sekali pada jam tertentu . 
5. Para guru diangkat oleh Departemen Agama.

6. Para guru agama diharuskan juga cakap dalam pendidikan umum.

7. Pemerintah menyediakan buku untuk pendidikan agama.

8. Diadakan latihan bagi guru agama.

9. Kualitas pesantren dan madrasah harus diperbaiki.

10. Pengajaran bahasa Arab tidak dibutuhkan.

Berdasarkan rekomendasi itu, pendidikan Islam berarti sangat terbatas pada pengajaran agama di sekolah mulai kelas IV, waktunya pun seminggu sekali, dan tidak termasuk pelajaran bahasa Arab. Dalam rekomendasi itu, pendidikan Islam dalam pengertian lembaga seperti pesantren dan madrasah tidak mendapat perhatian khusus, kecuali kalimat nomor $9:$ kualitas pesantren dan madrasah harus diperbaiki. ${ }^{34}$

\section{E. Pendidikan Islam Dalam Sistem Pendidikan Nasional}

Tantangan utama yang dihadapi para ahli dan praktisi pendidikan Islam dalam hal pengintegrasian madrasah ke dalam Sistem Pendidikan Nasional adalah menghapuskan dikotomi ilmu umum dan ilmu agama. Ilmu harus dipandang sebagai identitas tunggal yang telah mengalami perkembangan dalam sejarah. Perkembangan ilmu dalam sejarah menunjukkan bahwa

${ }^{34}$ Ibid, h. 48-50 
setiap peradaban manusia termasuk peradaban Islam telah memberi sumbangannya sendiri. ${ }^{35}$

Integrasi madrasah ke dalam Sistem Pendidikan Nasional menemukan bentuknya dalam Undang-Undang Sistem Pendidikan Nasional (UUSPN) yang dilansir pemerintah pada tahun 1989. Melalui UUSPN, madrasah mengalami perubahan definisi, dari sekolah agama menjadi sekolah umum berciri khas Islam. Perubahan definisi ini penting artinya, karena dengan demikian berarti madrasah tidak hanya mendapat legitimasi sepenuhnya sebagai bagian dari sistem pendidikan nasional. Oleh karena itu, UUSPN ini disambut dengan antusias oleh Depag, sebagai lembaga yang bertanggung jawab terhadap madrasah dan lembaga pendidikan Islam pada umumnya. ${ }^{36}$ Akan tetapi, perubahan definisi itu selanjutnya menuntut ada perubahan kurikulum. Karena madrasah tidak lagi sekolah agama, maka kurikulumnya harus didominasi oleh mata pelajaran umum. ${ }^{37}$

Tahun 1994 bisa jadi merupakan satu periode penting dalam perkembangan madrasah di Indonesia. Pada tahun itu, Depag telah menetapkan berlakunya kurikulum baru yang kemudian dikenal dengan kurikulum 1994 yang mensyaratkan pelaksanaan sepenuhnya kurikulum sekolah umum di bawah Departemen Pendidikan dan Kebudayaan. Berbeda dengan kurikulum

35 Ibid, h. 60

36 Ibid, h. 48

37 M. Ali Hasan, Mukti Ali,Kapita Selekta Pendidikan Islam (Jakarta: CV. Pedoman Ilmu Jaya, 2003), 61. 
sebelumnya bahwa madrasah memberikan $70 \%$ mata pelajaran umum dan 30\% mata pelajaran agama Islam, pada kurikulum 1994 madrasah diwajibkan menyelenggarakan sepenuhnya 100\% mata pelajaran umum sebagaimana diberikan di sekolah-sekolah umum di bawah Depdikbud.38Sekilas nampak memang bahwa yang paling menonjol dari kurikulum 1994 adalah penghapusan $30 \%$ mata pelajaran agama yang diajarkan sejak pemberlakuan kurikulum 1975. Namun bila dilihat lebih jauh, istilah penghapusan tersebut tentu tidak bisa dilihat semata-mata sebagai meniadakan mata pelajaran di madrasah.

Hal yang berlangsung pada dasarnya lebih merupakan perumusan kembali pemberian mata pelajaran madrasah. Ajaranajaran Islam tidak lagi diberikan dalam bentuk mata pelajaran formal., melainkan diintegrasikan secara penuh dalam mata pelajaran umum. Hal ini setidaknya bisa dilihat dari upaya Depag belakangan ini menyusun buku panduan guru mata pelajaran umum yang bernuansa Islam. Diharapkan, beberapa mata pelajaran umum diberikan di madrasah dengan tetap mempertahankan nuansa Islam. ${ }^{39}$ Dengan kurikulum 1994, dualisme ilmu agama dan ilmu umum di madrasah berusaha dihilangkan. Madrasah diharapkan menyelenggarakan pelajaran yang terintegrasi sepenuhnya dengan mata pelajaran umum. ${ }^{40}$ Namun dilihat dari sisi manapun, pendidikan Islam memiliki

${ }^{38}$ M. Ali Hasan, Mukti Ali,Kapita Selekta Pendidikan Islam, h. 61.

${ }^{39}$ Ibid. 62.

40 Ibid. 
peran dalam konteks pendidikan nasional. Hanya saja harus pula dimaklumi dan dipahami jika hingga hari ini secara kelembagaan pendidikan Islam kerap menempati posisi kedua dalam banyak situasi. Sebagai misal, jurusan yang menawarkan pendidikan Islam kurang banyak peminatnya, jika dibandingkan dengan jurusan lain yang dianggap memiliki orientasi masa depan yang lebih baik.

Dalam hal pengembangan kelembagaan akan pula terlihat betapa program studi/sekolah yang berada di bawah pengelolaan dan pengawasan Departemen Agama tidak selalu yang terjadi di bawah pembinaan Departemen Pendidikan Nasional (Depdiknas), bahkan harus dengan tertatih untuk menyesuaikan dengan yang terjadi di sekolah-sekolah umum tersebut. Meski disadari betapa pentingnya posisi pendidikan Islam dalam konteks pendidikan nasional. Namun, harus pula diakui hingga saat ini posisi pendidikan Islam belum beranjak dari sekadar sebuah subsistem dari sistem besar pendidikan nasional. Barangkali itulah yang menjadikan Ahmadi dalam pidato pengukuhan guru besarnya menyatakan posisi pendidikan Islam hanya sekadar suplemen.(Dalam Rozihan). ${ }^{41}$

\section{F. Kesimpulan}

Pendidikan Islam memiliki tiga fungsi dalam pembentukan kemajuan dan ahlak masyarakat. Pertama" Pendidikan Islam"

${ }^{41}$ http://www.suaramerdeka.com/harian/0501/07/opi3.htm 
sebagai sumber nilai adalah jenis pendidikan yang pendirian dan penyelenggaraannya didorong oleh hasrat dan semangat cita-cita untuk mewujudkan nilai-nilai Islam, baik yang tercermin dalam nama lembaganya, maupun dalam kegiatan-kegiatan yang diselenggarakan. Kedua, "Pendidikan Islam" sebagai bidang studi, sebagai ilmu, dan diperlakukan sebagai ilmu yang lain adalah jenis pendidikan yang memberikan perhatian sekaligus menjadikan ajaran Islam sebagai pengetahuan untuk program studi yang diselenggarakan. Ketiga, jenis pendidikan yang mencakup kedua pengertian di atas. Di sini kata Islam ditempatkan sebagai sumber nilai sekaligus sebagai bidang studi yang ditawarkan melalui program studi yang diselenggarakan.

Pengembangan Pendidikan Islam adalah lebih menekankan kepada aspek keimanan dan keyakinan dalam beragama dan selanjutnya mengembangkan orientasi pendidikan Islam yang menyangkut masalah-masalah sosial politik dan ekonomi (keduniawian) yang kemudian mendorong dilakukan penyesuaian pendidikan Islam, kurikulum, kelembagaan dan sistem pengajarannya. Terbukti dengan kemunculannya di Minangkabau, tahun 1906-1930, di Yogyakarta seperti Muhammadiyah, di Jakarta seperti Jam'iat Khair. Namun demikian, akhirnya ketentuan-ketentuan yang lebih tegas tentang pendidikan agama dalam pendidikan nasional telah direkomendasikan oleh Badan Pekerja Komite Nasional Pusat (BPKNP). Pendidikan Islam Dalam Sistem Pendidikan Nasional 
dapat dikatakan bahwa Sistem Pendidikan Nasional adalah menghapuskan dikotomi ilmu umum dan ilmu agama, madrasah mengalami perubahan definisi, dari sekolah agama menjadi sekolah umum berciri khas Islam.

Perubahan definisi ini penting artinya, karena dengan demikian berarti madrasah tidak hanya mendapat legitimasi sepenuhnya sebagai bagian dari sistem pendidikan nasional. Akan tetapi, perubahan definisi itu selanjutnya menuntut ada perubahan kurikulum. Karena madrasah tidak lagi sekolah agama, maka kurikulumnya harus didominasi oleh mata pelajaran umum.Ajaran-ajaran Islam tidak lagi diberikan dalam bentuk mata pelajaran formal, melainkan diintegrasikan secara penuh dalam mata pelajaran umum. Dengan kurikulum 1994, dualisme ilmu agama dan ilmu umum di madrasah berusaha dihilangkan. Madrasah diharapkan menyelenggarakan pelajaran yang terintegrasi sepenuhnya dengan mata pelajaran umum. Meski pendidikan Islam memiliki peran dalam konteks pendidikan nasional, hanya saja harus pula dimaklumi dan dipahami jika hingga hari ini secara kelembagaan, pendidikan Islam kerap menempati posisi kedua dalam banyak situasi. Dan harus pula diakui hingga saat ini posisi pendidikan Islam belum beranjak dari sekadar sebuah subsistem dari sistem besar pendidikan Nasional. 


\section{DAFTAR PUSTAKA}

al-Attas, Naquib, Muhammad, Syed, Konsep Pendidikan Islam; Suatu Rangka Pikir Pembinaan Filsafat Pendidikan Islam, Penerjemah Haidar Bagir. cet. VII (Bandung: Mizan, 1996).

Al-Ibrasyi, Atiyah, Muhammad, Dasar-Dasar Pendidikan Islam. Penerjemah Tasirun Sulaiman, cet. II (Ponorogo: PSIA, 1991).

Ali, Noer, Herry, Ilmu Pendidikan Islam (Jakarta: Logos, 1999).

Ali, mohamad, "Reorientasi Makna Pendidikan: Urgensi Pendidikan Terpadu," dalam Marzuki Wahid, dkk., ed., Pesantren Masa Depan (Bandung: Pustaka Hidayah, 1999).

Arifin, M. Ilmu Pendidikan Islam: Suatu Tinjauan Teori dan Praktis Berdasarkan Pendekatan Interdisipliner, cet. IV (Jakarta: Bumi Aksara, 1996).

An-Nahlawi, Abdurrahman, Prinsip-Prinsip dan Metode Pendidikan Islam. Penerjemah Herry Noer Ali (Bandung: CV. Diponegoro, 1989).

Anshari, Saefuddin, Endang, Pokok-pokok Pikiran Tentang Islam, (Jakarta: Usaha Enterprise, 1976).

Basri, Agus, Pendidikan Islam sebagai Penggerak Pembaharuan Islam (Bandung: Al-Ma'arif,1984).

Daulay, Putra, Haidar, Sejarah Pertumbuhan dan Pembaruan Pendidikan Islam di Indonesia, (Jakarta: Kencana Prenada Media Group, 2007).

Depag RI, Pola Pengembangan Pondok Pesantren. Jakarta: Ditpekapontren Ditjen Kelembagaan Agama Islam Depag, 2003.

http://www.suaramerdeka.com/harian/0501/07/opi3.htm

Langgulung, Hasan, Beberapa Pemikiran Tentang Pendidikan Islam, (Bandung: AlMa'rifah,1980). 
M. Ali Hasan, Mukti Ali, Kapita Selekta Pendidikan Islam (Jakarta: CV. Pedoman Ilmu Jaya, 2003).

Marimba, D. Ahmad, Pengantar Filsafat Pendidikan Islam, (Bandung: Al-Ma'rifah,1980).

Maksum, Madrasah, Sejarah, dan Perkembangannya, cet. II (Jakarta: Logos Wacana Ilmu, 1999).

Nata, Abuddin, Filsafat Pendidikan Islam (Jakarta: GayaMuda Pratama, 2005).

Ramayulis, Ilmu Pendidikan Islam (Jakarta: Kalam Mulia, 1994)

Zakiah Daradjat,Ilmu Pendidikan Islam, cet. III (Jakarta: Bumi Aksara, 1996).

Soegarda Poerbakawatja dan A. H. Harahap, Ensiklopedi Pendidikan, cet. II (Jakarta: Gunung Agung, 1981).

Sudjana, Nana, Pembinaan dan Pengembangan Kurikulum di Sekolah, cet. II (Bandung: Sinar Baru, 1991).

Yunus, Mahmud, Kamus Arab-Indonesia, cet. III (Jakarta: Hidakarya Agung, 1990), h. 138; Munjid, (Beirut: Dar el-Machreq, 1986).

Yunus, Mahmud, Pendidikan dan Pengajaran, cet. III (Jakarta: Hidakarya Agung, 1990).

Zahara Indris dan Lisna Jamal, Pengantar Ilmu Pendidikan, Jilid I (Jakarta: Grasindo,1992).

Zuhairini, dkk., Filsafat Pendidikan Islam, cet. II (Jakarta: Bumi Aksara, 1995). 